\begin{tabular}{c} 
Volume and Issues Obtainable at Center for Sustainability Research and Consultancy \\
Journal of Business and Social Review in Emerging Economies \\
ISSN: 2519-089X (E): 2519-0326 \\
Volume 6: No. 4, December 2020 \\
CSRC \\
Journal homepage: $\underline{\text { ww.publishing.globalcsrc.org/jbsee }}$ \\
\hline
\end{tabular}

\title{
The Development of a Questionnaire to Measure the Institutional Performance in Higher Education Institutions
}

\author{
${ }^{1}$ Gulshan Fatima Alvi, ${ }^{2}$ Nazma Bibi, ${ }^{3}$ Mahwish Safder, \\ ${ }^{1}$ Assistant Professor Lahore Leads University, Lahore, Pakistan, gulshan_fatima_alvi@yahoo.com \\ ${ }^{2}$ Assistant Professor Govt Degree College (W) Kot Khawaja Saeed, Lahore, Pakistan, \\ nazma.bibi@ymail.com \\ ${ }^{3}$ Assistant Professor Lahore Leads University, Lahore, Pakistan, mahwishsafder@gmail.com
}

\begin{tabular}{l}
\hline ARTICLE DETAILS \\
\hline History \\
Revised format: November \\
2020 \\
Available Online: December \\
2020 \\
\hline Keywords \\
Development, Institutional \\
Performance Questionnaire, \\
Standards, Higher \\
Education Institutions \\
\hline
\end{tabular}

JEL Classification

MO, M1

\section{OPEN ACCESS}

ABSTRACT

The objective of the study was to develop a questionnaire named IPQ (Institutional Performance Questionnaire) that measures the institutional performance of higher educational institutions. The scale comprised 11 subscales: Mission Statement and Goal (5 items), Planning and Evaluation (3 items), Organization \& Governance, (3 items), Integrity (3 items), Faculty (3 items), Students (2 items), Institutional Resources (3 items), Academic Programs and Curricula (3 items), Public Disclosure and Transparency (2 items), Assessment \& Quality Assurance (8 items), and Student Support Services (3 items). In total, 25 faculty members of the universities were selected by multistage stratified sampling, response to the questionnaire. The questionnaire was pilot tested and the Cronbach's alpha for the entire questionnaire was .951; for each subscale, alpha ranged from .623 to 0.823. Exploratory factor analysis was utilized to establish the construct validity of institutional performance in higher education institutions Findings of the study confirmed the validity and reliability of the IPQ (Institutional Performance Questionnaire).

(C) 2020 Center for Sustainability Research and Consultancy Pakistan under a Creative Commons Attribution-NonCommercial-ShareAlike 4.0

Corresponding author's email address: gulshan_fatima_alvi@yahoo.com

Recommended citation: Alvi, G. F., Bibi, N. \& Safder, M. (2020). The Development of a Questionnaire to Measure the Institutional Performance in Higher Education Institutions. Journal of Business and Social Review in Emerging Economies, 6(4), 1653-1663

\section{Introduction}

Universities impact the advancement of nations through their commitment to improved innovation, information move, advancing national solidarity, and supporting change and expanding productivity (Mugizi, 2018).Within the context of the national development, higher education institutions (HEIs) are the most important milestones of the knowledge-based economy (Secundo, Margherita, Elia, \& Passionate, 2010). HEIs are the underpinning organizations of the rational capacity building. Moreover, these institutions always seek for policy reforms that target at the progression of the entire education system (Chapman, 2009).

Hedin (2009) asserts that higher education institutions have been endeavoring to purposeful incredible 
performance towards attaining international measures of education. HEIs are considered as the main instruments for the national development.

In contemporary times, higher education institutions have a key role for the sustenance of any society, likewise the quality of education, modern trends of curriculum, competent faculty members and manpower resources are viewed as most imperative components for the development of higher education institutions (Rena, 2010). Quality of education transforms the traditional society into a modern society and efficient institutions are the major determinants for meeting the demands of the advance technologies in modern society. Measurement of institutional performance is a tool for the evaluation of institutions so that they may become efficient. With the passage of the time, researchers concentrated on the measurement of the institutional performance, so the initiative may take to achieve the required objectives of the efficient institutions.

In Pakistan,HEC (Higher Education Commission) is that body which is considered as a liable for consolidation and development of public and private sector universities. HEC was inaugurated in 2003 for the sake of quality assurance of educational institutions and also placed some standards for fullfledged Monitoring and performance evaluation of higher education institutions. Higher Education Commission consigns its aims and objectives according to the international expansion and practice. With the help of England Association of Schools and Colleges in 2005, and the middle states commission in 2006, the crucial arrangements were taken and eleven standards of accreditation were established by this commission to improve the performance of HEIs.

According to Batool, Qureshi, and Raouf (2010), the standards established by HEC, have substantial place in the global ranking of the higher education institutions. These standards aim to prospect the development and evaluate the effectiveness of higher educational institutions. Therefore, there is a need to develop a more comprehensive questionnaire that may base on performance evaluation standards of higher education institutions recommended by HEC (Higher Education Commission).

\section{Literature Review}

Institutional Performance (IP) indicates the hierarchical ability of an institution to achieve its objectives like gainfulness, solid monetary outcomes, a sizeable piece of the pie, quality items, consumer loyalty, and long term endurance (Sawalha, 2013). Institutional performance of higher education institutions subsists on a mission. All the tactics and measures are considered to get the successful achievement of the mission statement and objectives to the extent that establishes its productivity, usefulness with quality and excellence (Lambinicio, 2016).

Institutional performance can be measured through the availability of human and financial resources in order to attain the objectives. Especially, in profit-making organizations (Greenberg, 2011; Abubakar, 2017; Hilman, Kamyabi \& Devi, 2012).

During the examination of prior research, Carton (2004) focused on the institutional performance measurement and developed a questionnaire. The domain of institutional financial performance was empirically established and this measure also provided more relevant information about profitability, growth, cash flow, leverage and the efficiency of the institution. Validity and reliability of the constructs and measures were finally tested, and the questionnaire was also statistically evaluated. The nature of that research was exploratory. 
Antony and Bhattacharyya (2010) empirically developed a model for the measurement of institutional performance and institutional excellence. This model significantly contributes to distinguish the excellence level from the performance level. Managers of small and medium enterprises can use this model to evaluate the performance and excellence in segments.

PGF Consultants Inc. was ordered by the Forum of Federations to direct a developmental (mid-term) of Institutional Performance Evaluation, as required by its Grant Agreement with the Government of Canada 2005-2011. The reason for the evaluation was to survey the Forum's utilization of the funds and its prescribed results, efficiency, and effectiveness of the finance strategies (Meekison, 2008).

Chun and Rainey (2005) developed theoretically and methodologically more significant, four procedures of institutional performances those are, administrative usefulness, client service alignment, output, and work excellence. These measures are related to objective vagueness of U.S. federal government agencies' performance. Researchers prepared two larger reports on the agency's performance with the help of these measures that had the valid value of Cronbach's alpha series of .73 to .74

Brewer and Selden (2000) developed a model to evaluate institutional performance and proposed theoretical dimensions for it. They also classified the constructs to help in predicting the institutional performance that are managerial philosophy, human wealth and ability of leadership and control of individual-level factors (individual performance, task motivation, structure of work/task, public service motivation, task motivation). The model has good reliability with the Cronbach's alpha (.70 to .94).

Crucke and Decramer (2016) developed as a self-assessment tool to evaluate the social enterprise. They selected five performance domains named: financial performance, atmosphere performance, and public performance, human performance that are supporting in decision-making. Different members of the enterprise can use this tool easily. This tool is being tried to fill the gap through a most suitable instrument for the inner and exterior assessment of non-financial output of different groups in public enterprises. The results specified strong scale reliability 0.70 to 0.93 .

The researchers measured the performance in the light of academic results. Different trends of development also used for performance evaluation. Strong theoretical rationale of performance was also measured as important construct for management related researches (Richard, Devinney, Yip, \& Johnson, 2009; Liao \& Wu, 2009; Kirby, 2005).

Considering the above researches, sufficient information about the performance measurement scales and questionnaire have been described. All these measurements are the fundamentals for future development in different institution, but in Pakistan HEC (Higher Education Commission) is systematically executing the reforms for the improvement of performance in higher education institutions. Performance evaluations Standards are the primary step for the task accomplishment. The objective of this study is to develop a questionnaire for the measurement of institutional performance in higher education institutions, so that the anticipated certification to the quality provisions in higher education may be achieved. Moreover, these are the essentials for the international visibility and regional development of the country.

\section{Objectives}

1. To develop a questionnaire to measure the institutional performance in higher Education Institutions 
2. To develop the institutional performance evaluation system in higher education institutions under the eleven standards of accreditation recommended by HEC (Higher Education Commission).

\section{Conceptual Framework}

This study encompassed various features that were perceived in the conceptual framework of the study. The institutional performance in higher education institutions was estimated with the support of eleven standards of

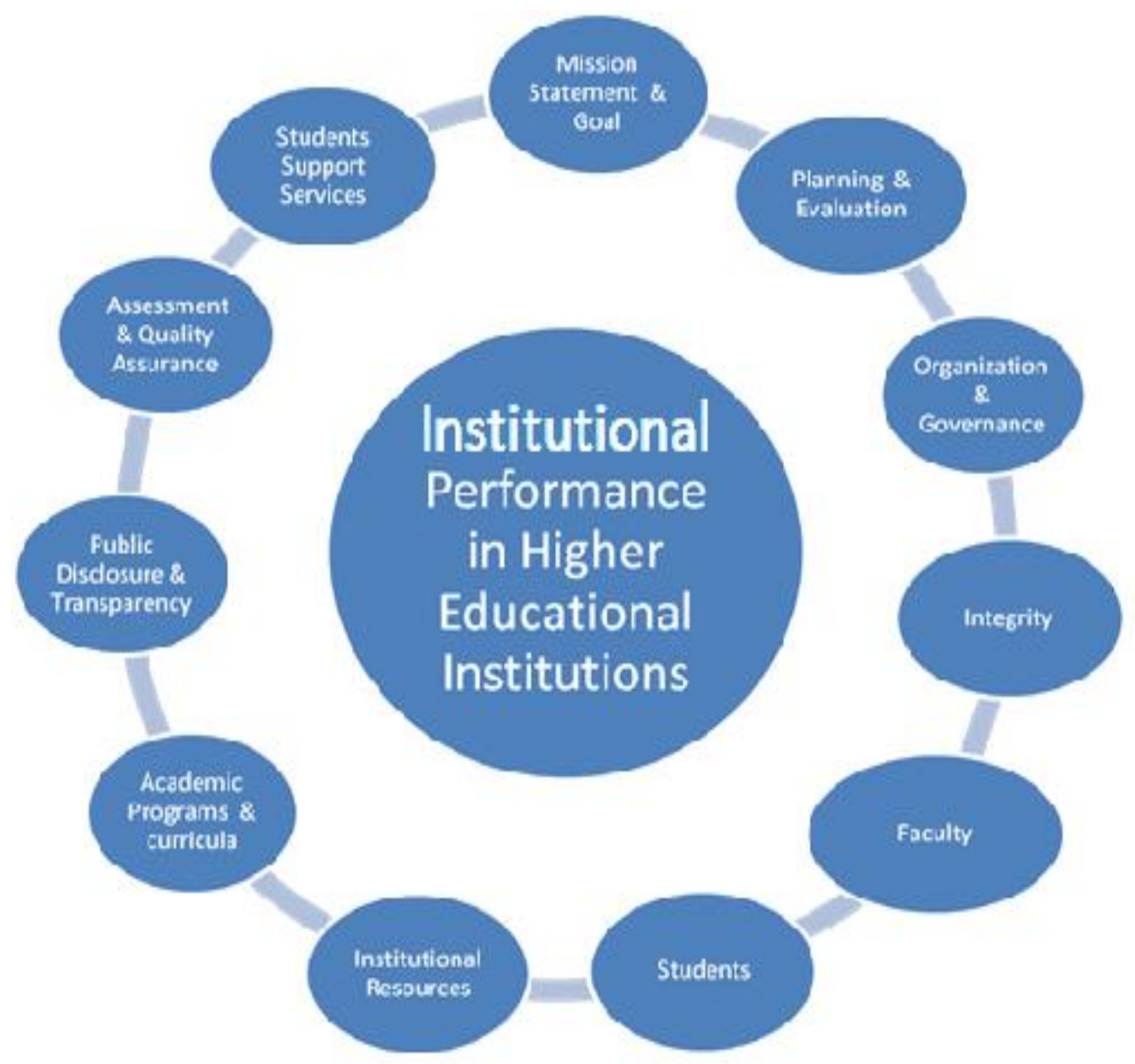

Figure 1.1 Conceptual frameworks for developing a questionnaire to measure the institutional performance in higher education institutions. 
accreditation by NEASC (England Association of Schools and Colleges, 2005) for the higher education institutions namely, Mission Statement and Goal, Planning and Evaluation, Organization and Governance, Integrity Faculty, Students, Institutional Resources, Academic Programs and Curricula, Public Disclosure \& Transparency, Assessment \& Quality Assurance, and Student Support Services.

\section{Methodology}

The scholars developed the IPQ (Institutional Performance Questionnaire) on the basis of these standards provided by Higher Education Commission.

Standard 1: Mission Statement and Goals Standard

2: Planning and Evaluation Standard 3: Organization

and Governance Standard 4: Integrity

Standard 5: Faculty

Standard 6: Students

Standard 7: Institutional Resources

Standard 8: Academic Programs and Curricula

Standard 9: Public Disclosure and Transparency

Standard 10: Assessment \& Quality Assurance

Standard 11: Student Support Services

\section{Goodness of Measures}

\subsection{Content and Face Validity}

Items of the questionnaire were given to the research experts at institute of Education \& Research in university of Punjab so that content and face validity may be confirmed. The researchers were rephrased the items according to the opinion of experts and also three items were dropped after the pilot study. The final items of the questionnaire were as followings.

\section{Standard 1: \\ Mission \\ Statement and Goals}

$\begin{array}{ll}\text { Standard } & \text { 2: } \\ \text { Planning } & \text { \& } \\ \text { Evaluation } & \end{array}$

- Faculty staff and governing authorities are involved to assign the activities and tasks according to mission statements and goals.

- Facilities and resource allocation for the accomplishment of the goals are sufficient.

- Mission and statements of goals are relevant within country context.

- All the faculty members are helpful for the accomplishments of these goals.

- Analysis reports of all the academic process are prepared at the end of short-term and long-term plans.

- Decision-making process is based on well-defined pre-planning and evaluation results

- Growth and development of higher educational institutes are assessed on a regular basis for quality improvement and accountability.

- Reviews of Allocated funds, grants and self-raised financial resources are properly managed under supervisory authority.
Institutional

Performance

Measurement 


\section{Standard $\quad 3$ Organization and Governance}

- All the members of governing body are adequate expert members keeping in view public interest

- Senior students have the opportunities to participate in the governance system.

- Faculty members communicate with each other and all other concerned participants and they also incorporates the results of self-assessments

- Factual reports about policy implementation process are periodically evaluated.
Standard
4:
Integrity and fair.
- The environment of institute is in favor of mutual respect for each other's suggestions and interests.

- Faculty hiring, promotion, and their compensation are transparent
Standard Faculty
5: $\quad$ - All the faculty members have a professional attitude.
- Curriculum is developed under the qualified and trained faculty members
- Evaluation criteria of academic program are appropriate under observation of senior faculty members.

Standard $\quad$ 6:
Students

Standard
Institutional
Resources

7:

- Resources are appropriately allocated according to the requirements of faculty and students relevant the execution of institutional goals.

- Strategies are well developed to measure the level of utilization of institutional resources.

- Physical infrastructure and facilities are the part of the Comprehensive master plan and life-cycle management plan including in the policy of higher education.

\section{Standard \\ 8: \\ Academic \\ Programs \\ and \\ Curricula}

- Faculty members are restricted to follow the course outline and they also plan the lesson before delivering the lectures.

- Curricula and syllabus content are correlated with institutional goals.

- The academic program quality standards are compatible with international purposes of student's survival in the society.

Standard 9: Public Disclosure and Transparency

\section{Institutional \\ Performance Measurement}




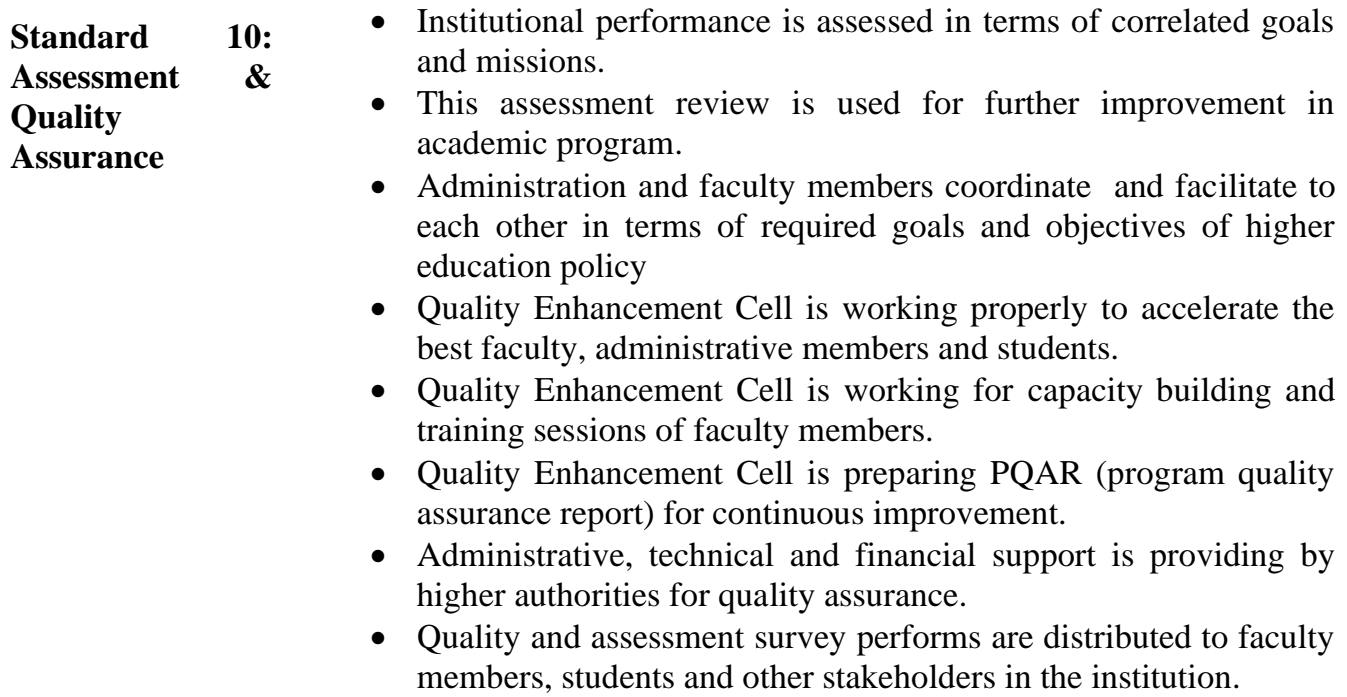

Standard 11: Student Support Services
- Guidance and counseling services of students are adequately processing.

- Athletics' programs are arranging regularly for consolidating the energies of students towards a beneficial competition.

- Students' complaints and grievances' reports are using for further benefits in favor of those students

Research instrument, Institutional Performance Questionnaire was pilot tested. Firstly two universities, Government College University, Lahore (public university) and University of Central Punjab, Lahore (private university) were randomly selected for this purpose. After the selection of the universities, Institutional Performance Questionnaire was distributed to the Deans of the Faculties and Heads of the Quality Enhancement Cells from both universities, and then also disseminated to the Heads of the Departments of the universities.

\section{Pilot test for Assessing Institutional Performance Questionnaire}

Table 1.2 Item statistics and item total correlation for assessing institutional Performance Questionnaire

\begin{tabular}{lcclcc}
\hline $\begin{array}{l}\text { Item } \\
\text { Number }\end{array}$ & $\begin{array}{l}\text { Mean } \\
\text { (Difficulty } \\
\text { Level) }\end{array}$ & $\begin{array}{l}\text { Item-total Correlation } \\
\text { (Discrimination Index) }\end{array}$ & $\begin{array}{l}\text { Item } \\
\text { Number }\end{array}$ & $\begin{array}{l}\text { Mean } \\
\text { (Difficulty } \\
\text { Level) }\end{array}$ & $\begin{array}{l}\text { Item-total } \\
\text { Correlation } \\
\text { (Discrimination } \\
\text { Index) }\end{array}$ \\
\hline IPQ 1 & 3.630 & .621 & IPQ 20 & 3.620 & .341 \\
IPQ 2 & 3.580 & .487 & IPQ 21 & 3.760 & .514 \\
IPQ 3 & 3.780 & .812 & IPQ 22 & 3.700 & .495 \\
IPQ 4 & 3.740 & .247 & IPQ 23 & 3.780 & .418 \\
IPQ 5 & 3.660 & .405 & IPQ 24 & 3.860 & .477 \\
IPQ 6 & 3.880 & .430 & IPQ 25 & 3.860 & .677 \\
IPQ 7 & 4.150 & .258 & IPQ 26 & 3.780 & .647 \\
IPQ 8 & 3.820 & .543 & IPQ 27 & 3.620 & .720 \\
IPQ 9 & 3.580 & .802 & IPQ 28 & 3.780 & .643
\end{tabular}




$\begin{array}{llllll}\text { IPQ 10 } & 3.100 & .520 & \text { IPQ 29 } & 3.740 & .669 \\ \text { IPQ 11 } & 3.280 & .570 & \text { IPQ 30 } & 3.660 & .624 \\ \text { IPQ 12 } & 3.620 & .718 & \text { IPQ 31 } & 3.540 & .637 \\ \text { IPQ 13 } & 3.630 & .602 & \text { IPQ 32 } & 3.740 & .349 \\ \text { IPQ 14 } & 3.660 & .751 & \text { IPQ 33 } & 3.540 & .533 \\ \text { IPQ 15 } & 3.700 & .690 & \text { IPQ 34 } & 3.540 & .520 \\ \text { IPQ 16 } & 4.040 & .509 & \text { IPQ 35 } & 3.780 & .643 \\ \text { IPQ 17 } & 3.660 & .741 & \text { IPQ 36 } & 3.860 & .667 \\ \text { IPQ 18 } & 3.620 & .436 & \text { IPQ 37 } & 3.840 & .381 \\ \text { IPQ 19 } & 3.380 & .672 & \text { IPQ 38 } & 3.870 & .532\end{array}$

Table 1.3 Scales Statistics

\begin{tabular}{lll}
\hline Mean & Std. Deviation & Cronbach's Alpha Reliability Coefficient \\
\hline 128.600 & 20.34746 & .941 \\
\hline
\end{tabular}

The Cronbach's alpha reliability coefficients and discriminating validity for the sub-scales of institutional performance survey were also described in the following table.

Table: 1.4 Descriptive Statistics, Reliability Coefficients and Discriminative Validity (in terms of mean correlations with scale)

\begin{tabular}{|c|c|c|c|c|c|}
\hline Variable & $\begin{array}{l}\text { No. of } \\
\text { Items }\end{array}$ & Mean & SD & $\begin{array}{l}\text { Cronbach's } \\
\text { Alpha }\end{array}$ & $\begin{array}{l}\text { Mean } \\
\text { Correlations }\end{array}$ \\
\hline Mission Statement and Goals & 5 & 17.470 & 2.175 & .686 & .212 \\
\hline Planning and Evaluation & 3 & 11.860 & 2.020 & .633 & .369 \\
\hline Organization \& Governance & 3 & 10.00 & 2.854 & .786 & .584 \\
\hline Integrity & 3 & 10.62 & 2.320 & .623 & .354 \\
\hline Faculty & 3 & 11.61 & 2.111 & .733 & 502 \\
\hline Students & 2 & 7.22 & 1.461 & .479 &. .314 \\
\hline Institutional Resources & 3 & 11.28 & 1,551 & .649 & .243 \\
\hline $\begin{array}{l}\text { Academic Programs and } \\
\text { Curricula }\end{array}$ & 3 & 12.81 & 1.924 & .750 & .498 \\
\hline $\begin{array}{l}\text { Public Disclosure and } \\
\text { Transparency }\end{array}$ & 2 & 8.50 & 1.607 & .762 & .613 \\
\hline Assessment \& Quality Assurance & 8 & 26.240 & 4.342 & .813 & .383 \\
\hline Student Support Services & 3 & 11.40 & 1.632 & .582 & .355 \\
\hline
\end{tabular}

Exploratory factor analysis was investigated to create the construct validity of the questionnaire that was defined in the following table. 
Table: 1.5 Factor loading of the questionnaire

\begin{tabular}{|c|c|c|c|c|c|c|c|c|c|c|c|}
\hline $\begin{array}{l}\text { Questi } \\
\text { ons } \\
\text { No. }\end{array}$ & $\begin{array}{l}\text { Factor } \\
1 \\
\text { Missi } \\
\text { on } \\
\text { State } \\
\text { ment } \\
\text { and } \\
\text { Goals }\end{array}$ & $\begin{array}{l}\text { Factor } \\
2 \\
\text { Plannin } \\
\text { g and } \\
\text { Evaluati } \\
\text { on }\end{array}$ & $\begin{array}{c}\text { Factor } \\
3 \\
\text { Organiza } \\
\text { tion and } \\
\text { Governa } \\
\text { nce }\end{array}$ & $\begin{array}{c}\text { Factor } \\
4 \\
\text { Integrity }\end{array}$ & $\begin{array}{l}\text { Factor } \\
5 \\
\text { Faculty }\end{array}$ & $\begin{array}{l}\text { Factor } \\
6 \\
\text { student }\end{array}$ & $\begin{array}{c}\text { Factor } \\
7 \\
\text { Instituti } \\
\text { onal } \\
\text { Resourc } \\
\text { es }\end{array}$ & $\begin{array}{c}\text { Factor } \\
8 \\
\text { Academic } \\
\text { Programs } \\
\text { and } \\
\text { Curricula }\end{array}$ & $\begin{array}{c}\text { Factor } \\
9 \\
\text { Public } \\
\text { Disclosur } \\
\text { e and } \\
\text { Transpar } \\
\text { ency }\end{array}$ & $\begin{array}{c}\text { Factor } \\
10 \\
\text { Assess } \\
\text { ment \& } \\
\text { Quality } \\
\text { Assuran } \\
\text { ce }\end{array}$ & $\begin{array}{c}\text { Factor } \\
11 \\
\text { Student } \\
\text { Support } \\
\text { Services }\end{array}$ \\
\hline Q1 & .923 & & & & & & & & & & \\
\hline Q2 & .819 & & & & & & & & & & \\
\hline Q3 & .872 & & & & & & & & & & \\
\hline Q4 & .919 & & & & & & & & & & \\
\hline Q5 & .848 & & & & & & & & & & \\
\hline Q6 & & .766 & & & & & & & & & \\
\hline Q7 & & .751 & & & & & & & & & \\
\hline Q8 & & .848 & & & & & & & & & \\
\hline Q9 & & & .872 & & & & & & & & \\
\hline Q10 & & & .880 & & & & & & & & \\
\hline Q11 & & & .848 & & & & & & & & \\
\hline Q12 & & & & .776 & & & & & & & \\
\hline Q13 & & & & .838 & & & & & & & \\
\hline Q14 & & & & .742 & & & & & & & \\
\hline Q15 & & & & & .672 & & & & & & \\
\hline Q16 & & & & & .914 & & & & & & \\
\hline Q17 & & & & & .810 & & & & & & \\
\hline Q18 & & & & & & .756 & & & & & \\
\hline Q19 & & & & & . & .862 & & & & & \\
\hline Q20 & & & & & & & .829 & & & & \\
\hline Q21 & & & & & & & .746 & & & & \\
\hline Q22 & & & & & & & .646 & & & & \\
\hline Q23 & & & & & & & & .943 & & & \\
\hline Q24 & & & & & & & & .812 & & & \\
\hline Q25 & & & & & & & & .858 & & & \\
\hline Q26 & & & & & & & & .870 & & & \\
\hline Q27 & & & & & & & & .822 & & & \\
\hline Q28 & & & & & & & & & .878 & & \\
\hline Q29 & & & & & & & & & .825 & & \\
\hline Q30 & & & & & & & & & & .829 & \\
\hline Q31 & & & & & & & & & & .740 & \\
\hline Q32 & & & & & & & & & & .828 & \\
\hline Q33 & & & & & & & & & & .723 & \\
\hline Q34 & & & & & & & & & & .822 & \\
\hline Q35 & & & & & & & & & & .878 & \\
\hline Q36 & & & & & & & & & & .829 & \\
\hline Q37 & & & & & & & & & & & .758 \\
\hline Q38 & & & & & & & & & & & .745 \\
\hline
\end{tabular}

pilot study was carried out. Descriptive Statistics, Reliability Coefficients and Discriminative Validity (in terms of mean correlations with questionnaire) were taken into account. The results legitimate that Institutional Performance Questionnaire and its subscales have good criterion-related validity and also 
construct validity.

The study revealed the scale Cronbach's Alpha Reliability Coefficient value was .951 and the subscales alpha ranged from .623 to 0.823 . Exploratory factor analysis was applied to ensure the construct validity of instrument.

As others measured described in different studies (Brewer \& Selden 2000; Carton 2004; Chun \& Rainey 2005; Meekison, 2008; Crucke \& Decramer, 2016) all the measures had been systematically conducted with good construct and criterion validity. The researchers conceptualized different constructs like Organizational Culture, Human Capital and Capacity, Leadership and Supervision and Individual-Level Factors (Structure of Task/Work, Task Motivation, Public Service Motivation, and Individual Performance), managerial effectiveness, customer service orientation, productivity, and work quality. The alpha value of all measures ranged from 0.70 to .0 .93 .

The Institutional Performance Questionnaire was significantly developed for the higher education institutions according to the international standard of accreditation in higher education institutions that portrayed also the strength of the HEC (higher education commission). Main focus of this questionnaire was to evaluate the performance of higher education institutions because HEIs are the spinal column and prosperity of a nation. This study provides a conceptual framework also that how the performance of higher education institutions can be improved. The researchers endeavored to cover all the performance indicators and provisions that made a considerable contribution by analyzing mission, planning and evaluation, assessment and quality assurance etc. Statistical results of the study authenticated that this questionnaire can be used for the performance evaluation of the universities because the well awareness of change leads towards betterments and provide best educational opportunities.

\section{Practical Implications}

This study provides a strategy for questionnaire design to measure the institutional performance in higher education institutions. This questionnaire is based on the eleven standards of accreditation that brings out the starting point for educational management towards rational initiatives. It may also helpful to fill the gaps between development and implementations of policy reforms in higher education institutions. This research also represents a resourceful contribution to the expansion of international performance evaluation standards especially for developing countries.

\section{References}

Antony, J. and Bhattacharyya, S. (2010), "Measuring organizational performance and organizational excellence of SMEs - Part 2: an empirical study on SMEs in India", Measuring Business Excellence, Vol. 14 No. 3, pp. 42-52. https://doi.org/10.1108/13683041011074209

Batool, Z., Qureshi, R., \& Raouf, A. (2010). Performance evaluation standards for the HEIs. Islamabad: Higher Education Commission.

Brewer, G. and Selden, S. (2000). Why Elephants Gallop: Assessing and Predicting Organizational Performance in Federal Agencies. Journal of Public Administration Research and Theory, 10(4), pp.685-712

Carton, R. (2004). Measuring Organizational Performance: An exploratory study. Ph.D. University of Georgia.

Chapman, D.W. (2009), Teacher Motivation: Incentives and working conditions, policy brief no. 9, Secondary teachers in Southeast Asia Project, World Bank, Washington, DC.

Chun, Y. \& Rainey, H. (2005). Goal Ambiguity and Organizational Performance in U.S. Federal Agencies. Journal of Public Administration Research and Theory, 15(4), pp.529- 557.

Crucke, S. \& Decramer, A. (2016). The Development of a Measurement Instrument for the Organizational Performance of Social Enterprises. Sustainability, 8(2), p.161.

Greenberg, J. (2011). Behavior in organizations (10th ed.). Upper Saddle River, NJ: Prentice Hall

Hedin,S. ( 2009).Higher education institutions as drivers of regional development in the Nordic countries. Nordegio Working Paper, Stockholm, Sweden. 
Hilman, H. (2009). Relationship of competitive strategy, strategic flexibility and sourcing strategy on organizational performance (Unpublished PhD thesis). Universiti Putra Malaysia, Malaysia.

Kamyabi, Y., \& Devi, S. (2012). The impact of advisory services on Iranian SME performance: An empirical investigation of the role of professional accountants. South African Journal of Business Management, 43, 61-72.

Kirby, J. (2005, July-August). Toward a theory of high performance. Harvard Business Review, 83(7), 30-39.

Lambinicio, J. (2016). Organizational performance of higher education institutions in Pangasinan, Third Asia Pacific Conference on Advanced Research, Melbourne.

Liao, S. H., \& Wu, C. C. (2009). The relationship among knowledge management, organizational learning, and organizational performance. International Journal of Business and Management, 4(4), 64-76.

Meekison, P. (2008). Organizational Performance Evaluation. Ottawa, Ontario: PGF Consultants Inc.

Rena, Ravinder. (2010). Emerging trends of higher education in developing countries.

Scientific Annals of the Alexandru Ioan Cuza University of Iasi: Economic Sciences Series. vol. 2010SE, 301-316.

Richard, P. J., Devinney, T. M., Yip, G. S., \& Johnson, G. (2009). Measuring organizational performance: Towards methodological best practice. Journal of Management, 35, 718-804. 